TITLE:

$<$ Book Reviews>Allison J. Truitt. 『Dreaming of Money in Ho Chi Minh City』Seattle: University of Washington Press, 2013, xii+193p.

$\operatorname{AUTHOR}(\mathrm{S}):$

MacLean, Ken

\title{
CITATION:
}

MacLean, Ken.<Book Reviews>Allison J. Truitt. 『Dreaming of Money in Ho Chi Minh City』Seattle: University of Washington Press, 2013, xii+193p.. Southeast Asian Studies 2015, 4(1): 206-209

ISSUE DATE:

2015-04

URL:

http://hdl.handle.net/2433/197732

RIGHT:

(C) Center for Southeast Asian Studies, Kyoto University 
People. New Delhi: Hindustan Pub. Corp.

Wang, Zhusheng. 1997. The Jingpo: Kachin of the Yunnan Plateau. Tempe, AZ: Program for Southeast Asian Studies.

Wyatt, David K. 1997. Southeast Asia 'Inside Out,' 1300-1800: A Perspective from the Interior. Modern Asian Studies 31(3): 689-709.

\section{Dreaming of Money in Ho Chi Minh City}

\section{Allison J. TruitT}

Seattle: University of Washington Press, 2013, xii +193p.

The scholarly study of banknotes (notaphily) is not a new phenomenon. But it did not take systematic modern form until the 1920s. (Ironically, it emerged under the Weimar Republic just as Germany was entering a three-year period of hyperinflation.) Since then, the number of numismatic associations has grown considerably, as have specialized publications. Banknote News is one relevant example. Banknote News issues breaking stories about international paper and polymer money. Collectors are the primary audience, and the website contains hundreds of links to vendors for people who wish to purchase the bank notes they covet. One of the links directs collectors to the 2014 edition of The Banknote Book. It includes 205 stand-alone chapters, each of which can be purchased separately as a country-specific catalog. (The Vietnam chapter provides detailed information on notes the State Bank of Vietnam issued, but only from 1964 to present, color copies of them, as well as their current market valuations.) The four-volume set currently runs 2,554 pages and details more than 21,000 types and varieties of currency, some dating back centuries.

The global community of currency collectors and the desires that shape their relationships to different forms of money provides a useful entry point into Allison Truitt's fascinating book, Dreaming of Money in Ho Chi Minh City. Truitt is similarly interested in state-issued currencies, especially with regard to how people conceptualize the interplay of their material and symbolic properties. But her interests do not end there. The ethnographic focus of the book is instead upon interpersonal relations, as mediated by different currencies (primarily coins, paper, and gold), which she dubs "monetary pluralism" (pp. 149-150).

The author's attention to interpersonal relations enables her to raise new questions about the cultural politics of identity in Vietnam's economic capital, Ho Chi Minh City, which she rightfully acknowledges is not always representative of the country as a whole. Nevertheless, the central questions around which the book is organized are not specific to it. The questions are applicable everywhere, and I reproduce them here for this reason. First, she asks, "Can people exert control over state-sponsored infrastructures such as territorial currencies?" Second, "How do we come to have faith in the currency we handle?" Third, "How do people personalize money so that it becomes a vehicle for expressing qualities other than exchange value?" And, finally, "What hap- 
pens when those efforts fail?” (pp.3-4).

The author describes how ordinary people—butchers, unlicensed money changers, small shop owners, street traders, lottery ticket purchasers, and so on-responded to the above questions over the course of six chapters. The first chapter provides a historical account of the "problem" competing currencies (Indochinese piasters, revolutionary-era financial notes, U.S. dollars, gold bars, and demonetized national currency) posed for people living in the south during the twentieth century. Chapter two features the rise of consumer culture, a process that began during the mid1990s when a series of reforms known as "Renovation"(Doi moi) accelerated the shift from a centralized command-and-control economy to a decentralized marked-based one. Truitt's insights into what this process looked like at the household-level lays the foundation for chapter three. It features the methods prosperous households used to hide their growing wealth and to maintain its value in the face of mounting inflation, a consequence of the country's gradual reintegration into global financial markets. Chapter four reorients the reader's attention to the role "fictive" currencies, such as "spirit" money (tien ma), play in Vietnamese ritual life. Particular emphasis is placed upon how "subjective" debts rather than "contractual" debts are (re-)produced through social interactions, and the complicated ways they link people over time and across territorial spaces. Chapter five, though very brief, presents an intriguing discussion of how Vietnamese assess the quality of cash with regard to its physical "appearance, feel, even its denomination" (p. 107). These assessments shape everyday interactions with others due to the prevalence of counterfeit notes, the frequency with which people reject bills that are either too worn or too large to make change, as well as the challenges banks face in terms of enrolling customers in what is still a predominantly cash-and-carry society. The final chapter features the strategies people employ to transform little money into big money through a range of illicit activities, most commonly by: participating in underground lotteries, speculating on land-use certificates (buying and selling land is still illegal), and investing in over-the-counter markets rather than the stock exchange to avoid state controls created to limit price fluctuations.

The resurgence of interest in the anthropology of money began several years ago. This book, with its insightful discussion of money and the role it plays in shaping new subjectivities, is a welcome contribution to this literature. According to one of the leading figures in this field, Bill Maurer, scholarship on this topic typically falls into one of three broad categories: the large-scale transformations of economic systems; the relationship between quantification and commensuration; and the materiality and fictions of finance (2006). Truitt's book intersects with all three subfields, and it demonstrates what can be gained by working across their boundaries in addition to within them. For example, she challenges simple, linear assumptions about the ascendancy of neoliberalism in Vietnam following decades of state socialism. Her findings instead show that the "transition" from one economic regime to another has not replaced prior relationships to money and value, some of which date back to the colonial period. Instead, these relationships continue to 
coexist-in ways that are harmonious at some moments and contradictory at others. Similarly, her field data demonstrates that the "gift economy" still flourishes despite the increasing commodification of everyday life. It does so, she elaborates, precisely because the perpetuation of "subjective" debts (on), i.e. social and moral obligations, is always asymmetrical and thus incommensurate in nature, which paradoxically strengthens rather than weakens social ties. Finally, she explains why speculative economies are not limited to the financial sector, but crucially shape the accumulation of religious merit, especially among women, as well.

The book contains many more insights into economic beliefs, values, and practices among Vietnamese in Ho Chi Minh City. The author does not always adequately explain their broader significance, however. For instance, there is little discussion of the theoretical literature on the anthropology of money, including ethnographic studies conducted in post-communist Europe and post-socialist Asia, many of them at the same time as her field research (see, e.g.: Mandel and Humphrey 2002; Ngai 2003; Ledeneva 2008; Rofel 2012). Admittedly, the book is written for the educated readers, not simply specialists. Nevertheless, these studies also examine how culturally inflected understandings of "national integrity, political authority, and membership in a globalizing world" (p.3), to borrow her phrasing, are reflected in and shaped by the ways people talk about and use money. Some discussion of this literature, to highlight where patterns converge and where they do not, would open up greater space for comparative work, which is very much needed in this subfield.

The sheer number of ethnographic vignettes in each chapter is not always an asset either. The stories are rich in detail, and the author is able to convey what they mean, often in a highly in a nuanced manner, to the reader. But the chapters are thematically organized, not analytically driven. Consequently, the chapters can come across as a loosely linked series of "snapshots" into people's lives, which obscure in the process the book's theoretical contributions to debates in the literature.

The author conducted the bulk of the field research during 2001-02, supplementing it with a second trip in 2007. Based on this reviewer's experience, the author's analysis remains accurate. But the length of time that has passed raises an important question, which the brief epilogue does not sufficiently address. What changes have occurred since then? Attitudes about official corruption have undergone a noticeable shift, for example. There has been a steady increase in the percentage of people who purchase health and accident insurance as a hedge against the unknown rather than accepting such events as "fate." And, the numbers of Vietnamese who participate in leisure activities, such as tourism at home and abroad, have exploded along with the rise in household incomes. All of these trends affect how people in Ho Chi Minh City think, feel, and use money today and, in turn, how they interact with one another on an everyday basis. Such trends are noteworthy, and they deserve further study.

Despite these modest shortcomings, Truitt's book has laid a strong foundation for future 
research in this area. Scholars will find the book to be a valuable resource, as well as an excellent text for undergraduate courses. So, too, will general readers, particularly those interested in the complex lives of money in other cultural contexts.

Ken MacLean Department of International Development and Social Change, Clark University

\section{References}

Ledeneva, Alena. 2008. Blat and Guanxi: Informal Practices in Russia and China. Comparative Studies in Society and History 50(1): 118-144.

Mandel, Ruth; and Humphrey, Caroline. 2002. Markets and Moralities: Ethnographies of Post-Socialism. Oxford: Berg.

Maurer, Bill. 2006. The Anthropology of Money. Annual Review of Anthropology 35: 5-36.

Ngai, Pun. 2003. Subsumption or Consumption: The Phantom of Consumer Revolution in "Globalizing" China. Cultural Anthropology 18(4): 469-492.

Rofel, Lisa. 2012. The Traffic in Money Boys. Positions 18(2): 425-458.

\section{In Search of Middle Indonesia: Middle Classes in Provincial Towns}

Gerry VAN KLINKEN and WARD Berenschot, eds.

Leiden: KITLV Press; Boston: Brill, 2014, xvi+242p.

In 2012, the Indonesian Daily Kompas conducted a survey aiming to calculate the actual number and define the characteristics of what it called "the middle class cohort" of the country's population. Involving 2,550 people above 17 years of age who lived in the cities of Jakarta, Bandung, Yogyakarta, Surabaya, Makassar, and Medan, the survey employed the World Bank criteria of education level, occupation, and purchasing power parity (PPP) to determine the class categories of the respondents. The survey result shows that $1 \%$ of the respondents belonged to the upper class, $3.6 \%$ to upper middle class, $50.2 \%$ to middle class, $39.6 \%$ to lower middle class, and $5.6 \%$ to the lower class. In the World Bank criteria this means that the surveyed cohort groups, successively, earned and lived on more than US $\$ 20$ per day, between US $\$ 10$ and 20 , between US $\$ 4$ and 10 , between US $\$ 2$ and 4, and less than US\$2. This result echoes the World Bank's own survey earlier that year as quoted by the Daily Kompas, in which $56.5 \%$ of the entire Indonesian population of 237 million in 2012 - thus forming an actual number of 134 million people-is seen as belonging to the middle class category. Kompas and the World Bank surveys represent analyses of the socio-economic diversification of the Indonesian population over the past five years, which generally depicted a growing middle class. Whereas the criteria used for the grouping of the surveyed respondents perform an established standard of income and expenditure method typical of economists, they do 